\title{
STRUKTURY WEWNĄTRZWYRAZOWE WSPÓŁCZESNEGO OGÓLNONARODOWEGO JĘZYKA CHIŃSKIEGO
}

\author{
THE INSIDE WORD STRUCTURES \\ OF MODERN STANDARD CHINESE
}

\begin{abstract}
A b stract. The topic of the paper is to describe the inside word structures of Modern Standard Chinese. In the five parts of the paper, five groups of words are discussed: monomorphemic words, reduplications, affix formations, semanteme formations with the internal syntactic structure, and synthetic formations. Analyzed vocabulary consists of polysyllabic words, including those with the status of compound words.

In the first part of the article, the monomorphemic polysyllabic words are presented with a brief reference to the monomorphemic monosyllabic words. The second part describes the structure of words with the reduplication and their particular type-broken reduplication. In the third part, the affix formations are presented, including words containing proper affixes and quasi-affixes. The semanteme formations with subject-predicative, coordinative, determinative, rective and complementive structures, as well as the multisemanteme words containing stacked syntactic structures are discussed in the fourth section. Various types of synthetic formations, i.e. words formed by the combination of different types of the inside word structures, are presented in the fifth section.
\end{abstract}

Słownictwo współczesnego ogólnonarodowego języka chińskiego analizowano i opisywano przez ostatnie kilkadziesiąt lat na wiele rozmaitych sposobów. Poszczególne opracowania tych samych zagadnień znacznie się od siebie różnią, a często bywają nawet sprzeczne. Trudność jednolitego i dokładnego opisania tak szerokiego tematu, jakim jest słownictwo języka chińskiego, dostrzegał już w latach sześćdziesiątych Kratochvíl (1968:11).

Dagmara Sikora-MiaO - Katedra Sinologii na Wydziale Nauk Humanistycznych Katolickiego Uniwersytetu Lubelskiego Jana Pawła II; adres do korespondencji - e-mail: sunrise. chenxi@gmail.com 
Pisał on, że to, co powszechnie uważa się za oczywiste dla języków lepiej zbadanych, niekoniecznie musi odnosić się do języka chińskiego, a przynajmniej nie odnosi się do niego bez zastrzeżeń. Ocenił on, że wszelkie próby poważnej dyskusji na którykolwiek z tematów dotyczących języka chińskiego wydają się koncentrować raczej na kwestiach zasadniczych aniżeli na zagadnieniach spornych, wymagających dogłębnej analizy. Jednym z takich zagadnień są - według Zhu i Tian $(2000,2: 134)$ - formacje afiksalne. Zauważają oni niejednorodność w zasadniczych kwestiach, takich jak terminologia, dobór kryteriów czy definiowanie pojęć.

W niniejszym artykule skoncentruję się jedynie na najważniejszych dostępnych i znanych mi materiałach, dotyczących słownictwa ogólnonarodowego języka chińskiego, powstałych na przestrzeni ostatnich pięćdziesięciu lat. Nie jest moim celem ocena poziomu prac naukowych, do których będę się odwoływać, ani krytyka któregokolwiek z autorów, z których każdy wniósł nieoceniony wkład w lepsze zrozumienie struktur słownictwa współczesnego języka chińskiego. Jednym z celów tego artykułu jest pokazanie najistotniejszych różnic w podejściu do omawianego tematu. Istnienie takich różnic staje się zrozumiałe, kiedy weźmiemy pod uwagę fakt, że opracowania te powstawały $\mathrm{w}$ różnym czasie $\mathrm{i}$ miejscu, a wpływ na nie miały aktualny stan wiedzy o języku i trendy panujące w językoznawstwie. Na podstawie różnych prac naukowych postaram się przedstawić opis struktur słownictwa ogólnonarodowego języka chińskiego w formie jednolitej całości, zgodnej z teoriami współczesnego językoznawstwa.

W pierwszej części zostaną omówione wyrazy monomorfemiczne, w drugiej - wyrazy o strukturze reduplikacji. Afiksy oraz ich szczególny typ, czyli quasi-afiksy będą tematem części trzeciej, w której analizie zostaną poddane formacje afiksalne. W części czwartej zostaną przedstawione wewnętrzne struktury składniowe wyrazów semantemowych. Formacje syntetyczne zostaną opisane w części piątej.

\section{WYRAZY MONOMORFEMICZNE}

Wyrazy monomorfemiczne, czyli wyrazy składające się z jednego morfemu, dzielą się na dwie grupy. Wyrazy monomorfemiczne monosylabiczne to takie, w których jednemu morfemowi odpowiada jedna sylaba. Wyrazy monomorfemiczne polisylabiczne natomiast składają się z jednego morfemu utworzonego z kilku sylab. 


\section{WYRAZY MONOMORFEMICZNE MONOSYLABICZNE}

$\mathrm{Z}$ uwagi na to, że słownictwo monomorfemiczne monosylabiczne nie jest tematem tego artykułu, nie będzie ono szczegółowo omawiane. Krótki opis jest jednak niezbędny, gdyż wyrazy te stanowią podstawową część składową większości polisylabicznych i polimorfemicznych wyrazów ogólnonarodowego języka chińskiego.

Ogromna liczba wyrazów składających się z jednego morfemu, któremu odpowiada jedna sylaba, stała się - jak twierdzi Kratochvíl (1968:65) powodem popularnego twierdzenia, że język chiński jest językiem monosylabicznym. Według Künstlera (2000:16) o języku monosylabicznym mówimy wtedy, gdy podział wyrazu na sylaby pokrywa się z podziałem na morfemy. Monosylabizm nie jest jednak bezwzględną cechą języka chińskiego. Termin ten nie oznacza, że wszystkie wyrazy są jednosylabowe ani że w języku tym nie występują morfemy asylabiczne czy wielosylabowe. Jest to jedynie wyróżniająca ten język cecha charakterystyczna.

Do słownictwa monomorfemicznego monosylabicznego Kratochvíl (1968: 26-34) zalicza wyrazy należące do wszystkich kategorii gramatycznych. Pośród nich znajdują się m.in. 人 rén 'człowiek', 茶 chá 'herbata', 拉 $l \bar{a}$ 'ciągnąć, 笑 xiào 'śmiać się', 忙 máng 'zajęty', 全 quán 'całkowicie', 绿 lǜ 'zielony', 这 zhè ‘to', 八 $b \bar{a}$ 'osiem' oraz wiele innych.

\section{WYRAZY MONOMORFEMICZNE POLISYLABICZNE}

Wyrazy monomorfemiczne polisylabiczne to wyrazy zbudowane z jednego polisylabicznego morfemu. Według Kratochvíla (1968:65) stanowią one relatywnie małą grupę. Większość z nich to wyrazy obcego pochodzenia, które można podzielić na dwie podgrupy.

Do pierwszej Kratochvíl (1968:65) zalicza wyrazy, które weszły do języka chińskiego tak dawno, że ich pochodzenie jest albo hipotetyczne, albo nieznane. Są to konstrukcje zazwyczaj dwusylabowe z akcentem na pierwszą sylabę, np. 蝴蝶 húdié 'motyl'. W wielu przypadkach druga sylaba jest atonalna, np. 葡萄 pútao 'winogrono', 和尚 héshang 'buddyjski mnich' oraz 玻璃 $b \bar{o} l i$ 'szkło'. Do podgrupy tej należą także wyrazy określane przez Künstlera (2000:88) jako reduplikacje złamane typu „shuangsheng” i „dieyun", które zostaną omówione w dalszej części artykułu.

Drugą podgrupę tworzą, według Kratochvíla (1968:65), stosunkowo nowe zapożyczenia fonetyczne, pochodzące głównie z języków europej- 
skich. Znajdują się w niej takie wyrazy, jak 咖啡 kāfēe ' kawa', 坦克 tănkè 'czołg', 幽默 yōumò 'humor', 法西斯 făxīsī 'faszysta' czy 布尔什维克 bùěrshíwéikè 'bolszewik'. Do tej podgrupy zalicza się również większość niechińskich nazw własnych, np. 布宜诺斯艾利斯 Bùyínuòsìàilìs ì 'Buenos Aires' czy 贝多芬 Bèiduōfēn 'Beethoven'. W odróżnieniu od głównie dwusylabowych zapożyczeń niewiadomego pochodzenia zapożyczenia fonetyczne z języków europejskich to zwykle wyrazy składające się z trzech lub więcej sylab, w dodatku tonalnych.

Oprócz zapożyczeń do grupy wyrazów monomorfemicznych polisylabicznych Kratochvíl (1968:67) zalicza również wyrazy będące imitacjami dźwięków. Reprezentatywne dla tej podgrupy są takie wyrażenia, jak 哗啦 huālā 'łomotać', 'szeleścić' oraz 唧唧 $j i \bar{j} \bar{l}$ 'piszczeć', 'skrzypieć'.

Do tej podgrupy należą również wymieniane przez Künstlera (2000:85) wyrazy powstałe wskutek procesu dimidiacji, czyli rozbicia nagłosowych grup spółgłoskowych, w wyniku którego z pojedynczej sylaby powstała formacja dwusylabowa. Klasycznym przykładem dimidiacji jest wyraz 窟窡 kūlong 'dziura', 'jaskinia', w którym z morfemu monosylabicznego klong ${ }^{1}$ powstał morfem dwusylabowy kulong ${ }^{2}$.

Procesowi dimidiacji Künstler (2000:85) przeciwstawia proces kontrakcji, czyli ściągnięcia dwu sylab w jedną, np. 不 bù 'nie' + 用 yòng 'trzeba' = 犕 béng 'nie ma potrzeby'. Wyrazy powstałe w wyniku procesu kontrakcji należą jednak do całkiem innej grupy słownictwa, są to bowiem wyrazy polimorfemiczne monosylabiczne.

\section{REDUPLIKACJE}

Reduplikacją nazywa Künstler (2000:193) każde powtórzenie tego samego elementu, przy czym w języku chińskim mamy do czynienia wyłącznie ze zdwajaniem sylab, w związku z czym mówimy o reduplikacji sylabicznej. Wyjątek stanowią reduplikacje tak zwane niepełne, w których powtórzeniu ulega jedynie nagłos bądź wygłos sylaby.

Nie można przy tym wszystkich reduplikacji traktować jednakowo. Künstler (2000:193) zdecydowanie odróżnia reduplikację będącą cechą strukturalną danej grupy słownictwa od reduplikacji będącej wykładnikiem

\footnotetext{
${ }^{1}$ Wymowa zgodna ze współczesną transkrypcją pinyin.

${ }^{2}$ Wymowa zgodna ze współczesną transkrypcją pinyin.
} 
określonych funkcji. W tym artykule opisane zostaną wyłącznie wyrazy mające strukturę reduplikacji. Konstrukcje powstałe w wyniku procesu reduplikacji - jako konstrukcje składniowe - zostaną pominięte.

\section{WYRAZY O STRUKTURZE REDUPLIKACJI}

Do wyrazów o strukturze reduplikacji Künstler (2000:87-88) zalicza impresywa, inaczej: wyrazy impresywne, czyli naśladujące dźwięki oraz oddające przeróżne wrażenia. Charakterystyczne impresywa pochodzące już $\mathrm{z}$ języka archaicznego ${ }^{3}$ to $\mathrm{np}$. 洋洋 yángyáng 'rozległa przestrzeń wodna' czy 巍巍 weeiwei lub 嵬嵬 wéiwéi 'majestatyczny (jak wysoko wznosząca się skała)'. Impresywa o strukturze reduplikowanej są, według Künstlera, wyrazami, w których nie można wyróżnić monosylabicznego morfemu rdzennego będącego podstawą reduplikacji. Pominąwszy sztuczne sytuacje słownikowe, w których poszczególnemu znakowi pisma przypisuje się znaczenie całego wyrazu impresywnego, monosylabiczne elementy tworzące impresywum nie występują samodzielnie. Są to zatem wyrazy nierozkładalne, co oznacza również, że między dwoma sylabami takiej reduplikacji nie zachodzą żadne stosunki typu składniowego. Reduplikacje impresywne Künstler (2000:193) nazywa reduplikacjami pełnymi, w odróżnieniu od reduplikacji niepełnych, czyli złamanych, o których będzie mowa w dalszej części artykułu.

Charakter reduplikacji mają również wyrazy, których komponentami są morfemy związane, a więc takie, które posiadają znaczenie leksykalne, lecz nie mogą funkcjonować jako samodzielne wyrazy. Li i Thompson (1981:3536) kwalifikują do tej grupy terminy będące nazwami związków pokrewieństwa, np. 姐姐 jiějie 'starsza siostra' czy 弟弟 didi 'młodszy brat'. Za wyjątki uważają w tej grupie wyrazy 爸爸 bàba 'tata' i 妈妈 māma 'mama', w których morfemy 爸 $b a ̀$ i 妈 $m \bar{a}$ są morfemami swobodnymi, a więc takimi, które mogą być samodzielnymi wyrazami. Innymi przykładami reduplikacji określających związki pokrewieństwa są np. 爷爷 yéye 'dziadek ze strony ojca', 姥姥 lăolao 'babka ze strony matki' czy 公公 gōnggong 'teść ze strony męża'. Według Chao (1968:201-202) reduplikacjami tego typu są również wyrazy nazywające relacje międzyludzkie, np. 太太 tàitai 'pani', 'żona' a także inne rzeczowniki, np. 娃娃 wáwa 'lalka', 蛛蛛 zhūzhu 'pająk', 猩猩 xīngxing 'orangutan', w tym rzeczowniki przyjmujące sufiks

${ }^{3}$ Archaiczny język chiński (AC) jako termin gramatyczny odnosi się do okresu od ok. XI wieku p.n.e. do mniej więcej końca III wieku p.n.e. (KÜNSTLER, 2000:72). 
儿 -er, np. 蚛蝈儿 guōguor 'amerykański konik polny' czy 蛐蛐儿 qūqur 'świerszcz'.

Chao $(1968: 199,204,206)$ wyróżnia także nieliczną grupę, w której reduplikacją nie jest cały wyraz, a jedynie jego część składowa. Li i Thompson (1981:36) zaznaczają, że są to wyrazy, w których nie można wyróżnić ich podstawowej niezreduplikowanej formy. Chao podaje takie przykłady jak 朦朦雨 méngméngy̌́ 'dżdżysty deszcz', 嘎嘎本儿 gágazăor 'rodzaj daktyla o ostrym końcu', 打哈哈 dăhāha 'żartować', 'przekomarzać się' oraz 直挺挺 zhitǐngtǐng 'prosty i sztywny'.

\section{REDUPLIKACJE ZŁAMANE}

Do reduplikacji niepełnych, zwanych złamanymi, należą przede wszystkim wyrazy, które w tradycji chińskiej określane są terminami „shuangsheng” 双声 shuāngshēng "podwójny nagłos' i „dieyun” 叠韵 diéyùn 'powtórzony wygłos'. Künstler (2000:88) definiuje pierwszy typ jako wyrazy mające takie same nagłosy, lecz różne rymy, np. 仿佛 făngfú 'wydawać się', 'jakby'. Drugi typ definiuje jako wyrazy o identycznych rymach i różnych nagłosach, jak 螳螂 tángláng 'modliszka' czy 苜宿 mùxu 'lucerna'. Większość reduplikacji złamanych to rzeczowniki. Kratochvíl (1968:65) podaje przykłady dawnych zapożyczeń o hipotetycznym lub niewiadomym pochodzeniu. Należą do nich zarówno wyrazy typu ,shuangsheng”, np. 蜘蛛 zhīzhu 'pająk', 琵琶 pipa 'czterostrunowy instrument szarpany' czy 枇杷 pípa 'niesplik japoński', jak i wyrazy typu „dieyun”, np. 蜻蜓 qingtíng 'ważka', 橄榄 gănlăn 'oliwka', 徘徊 páihuái 'poruszać się w przód i w tył' czy 啰嗦 luōsuo 'paplać'.

Wyrazy impresywne również mogą mieć strukturę reduplikacji złamanych. Takimi są wymienione przez Kratochvíla (1968:67) imitacje dźwięków, np. 咕噜 gū $\bar{l} \bar{u}$ 'bulgotać' oraz 叮当 dīngdāng 'dzwonić', 'brzękać'.

\section{FORMACJE AFIKSALNE}

Formacje afiksalne stanowią dosyć pokaźną i stale rosnącą grupę słownictwa współczesnego języka chińskiego. Są to wyrazy powstałe w procesie, który Encyklopedia językoznawstwa ogólnego [EJO] (2003:19) nazywa afiksacją, czyli dołączeniem segmentu morfologicznego zwanego afiksem do morfemu lub ciągu morfemów. Tabakowska (2001:77) podaje, że w zależno- 
ści od pozycji, jaką afiks zajmuje względem morfemu głównego, czyli rdzenia, możemy mówić o prefiksach, czyli morfemach pobocznych stojących przed morfemem rdzennym, oraz o sufiksach, będących morfemami pobocznymi zajmującymi pozycję po rdzeniu. Badacze języka chińskiego zgodni są co do istnienia tych dwóch rodzajów afiksów we współczesnym języku chińskim. Obecność trzeciego rodzaju morfemów pobocznych jest kwestią sporną. Za ich wyróżnieniem postuluje np. Chao (1968:257) oraz Li i Thompson (1981:36). Przeciwnego zdania są Kratochvíl (1968:68) czy Künstler (2000:231). Mowa tu o afiksach zajmujących pozycję wewnątrz morfemu rdzennego, czyli o takich morfemach segmentalnych, które Encyklopedia językoznawstwa ogólnego (2003:254) nazywa infiksami. Afiksy są w języku chińskim grupą bardzo niejednorodną, w związku z czym oprócz afiksów właściwych, będących typowymi morfemami pobocznymi, wyróżniono również takie morfemy, które - choć nie mają cech typowych afiksów - zachowują się podobnie do nich. $\mathrm{Z}$ tego względu nazwano je formami afiksopodobnymi, czyli quasi-afiksami.

Afiksy można analizować i klasyfikować pod wieloma różnymi względami. Tak na przykład, biorąc za kryterium pozycję, jaką afiksy zajmują wobec rdzenia, dzielimy je na prefiksy, np. 老 lăo- lub 单 dān-bądź sufiksy, $\mathrm{np}$. 头 -tou czy 家 -jiā. Stopień sformalizowania, czyli gramatykalizacji ${ }^{4}$, morfemów pozwala nam oddzielić nieliczne afiksy właściwe, np. 阿 $-\bar{a}$ lub 子 -zi od quasi-afiksów, np. 反 făn-, 性 -xìng czy 手 -shǒu. Wreszcie liczba sylab, z których składa się afiks, daje nam możliwość mówienia o afiksach mono- i polisylabicznych, np. 者 -zhě i 主义 -zhǔyì. Gdy chcemy ocenić stopień produktywności danego afiksu, należy brać pod uwagę jego zdolność do łączenia się z morfemami rdzennymi. Według Chena (2001:20) afiksy bywają wysoce produktywne, kiedy łączą się z dużą liczbą rdzeni, bądź nieproduktywne, jeśli rdzeni, z którymi mogą się łączyć, jest niewiele. Oprócz tego afiksy mogą wyznaczać zarówno klasy semantyczne, jak też określać przynależność utworzonego przez nie wyrazu do poszczególnych kategorii gramatycznych. Zhu i Tian $(2000,2: 134)$ podają przykład quasisufiksu 员 -yuán, który przyporządkowuje wyraz do klasy „osób wykonujących dany zawód" oraz kategoryzuje go jako rzeczownik. Ponadto ze względu na funkcję afiksy dzielą się na afiksy słowotwórcze i gramatyczne. Zhu i Tian $(2000,2: 137)$ za afiksy słowotwórcze uważają takie morfemy poboczne, które służą do budowania nowych wyrazów. Afiksami gramatycz-

\footnotetext{
${ }^{4}$ Gramatykalizacja - utrata przez element leksykalny pierwotnego znaczenia i przejście w morfem gramatyczny (ZAJDLER, 2005:66).
} 
nymi nazywają takie morfemy, które nie tworzą nowych wyrazów, a jedynie wskazują na ich funkcje gramatyczne. Autorzy ci uważają, że czysto gramatycznych morfemów pobocznych w języku chińskim jest bardzo niewiele. Niektóre afiksy gramatyczne są jednocześnie afiksami słowotwórczymi, np. sufiks 们 -men. Tworzy on zarówno nowe wyrazy, np. 我们 wǒmen 'my', 他们 tāmen 'oni', jak również wskazuje na ich liczbę mnogą.

\section{WYRAZY ZAWIERAJĄCE AFIKS WŁAŚCIWY}

Większość afiksów w języku chińskim, jak podają Zhu i Tian $(2000,2$ : 136), powstało w wyniku gramatykalizacji morfemów leksykalnych. Proces ten trwa do chwili obecnej, w związku z czym stopień gramatykalizacji morfemów w poszczególnych wyrazach jest różny. W pełni zgramatykalizowane morfemy zgodnie uznaje się za afiksy właściwe, natomiast częściowo zgramatykalizowanym nadano nazwę quasi-afiksów.

Afiksy właściwe okazują się być grupą bardzo nieliczną, gdyż - jak pisze Künstler (2000:234) - za afiks uznać można jedynie taki element, który utracił swoje podstawowe znaczenie oraz został pozbawiony swych istotnych cech, takich jak akcent przyciskowy ${ }^{5}$ czy ton. Zhu i Tian $(2000,3: 136)$ dodają, że takie afiksy nie mogą tworzyć innych wyrazów, w których byłyby morfemami leksykalnymi, czyli posiadającymi znaczenie leksykalne. Tu potrzebna jest pewna dygresja. Ci sami autorzy (ZHU i TIAN, 2000,2:134) wyjaśniają, że w języku chińskim jednemu morfemowi w wymowie odpowiada jedna sylaba, w zapisie odpowiada mu jeden znak. Nie jest tak w każdym przypadku, jakkolwiek jest to cecha, która w sposób szczególny charakteryzuje język chiński. W związku z tym mamy do czynienia ze sporą liczbą morfemów o tym samym brzmieniu i tej samej formie graficznej. W rzeczywistości są one jednak różnymi jednostkami języka, których znaczenie gramatyczne także jest różne. Przykładem niech będzie morfem 老 lăo, który może funkcjonować albo jako prefiks, np. w wyrazie 老师 lăoshī 'nauczyciel', albo jako morfem leksykalny, np. w 老人 lăorén 'starzec', albo jako samodzielny wyraz 'starzeć się', np. w 他老了 tā lăo le 'zestarzał się'.

Afiksy właściwe, na które składają się prefiksy i sufiksy, są więc grupą dość nieliczną. Większość autorów do prefiksów zalicza zaledwie cztery czy

5 Akcent przyciskowy - element suprasegmentalny, tj. niemający segmentu czasowego, w którym wyróżnia się co najmniej trzy stopnie: akcent przyciskowy mocny, słabszy i najsłabszy, a także brak akcentu (KÜNSTLER, 2000:227-228). 
pięć morfemów. Sufiksy występują nieco częściej, liczba ich jest jednak różna w zależności od definicji, jaką przyjmuje się na ich określenie.

\section{WYRAZY ZAWIERAJĄCE PREFIKS WŁAŚCIWY}

Większość badaczy za typowe prefiksy w języku chińskim uważa: 阿 $\bar{a}$-, 老 lăo-, 第 dì- oraz 初 chū-. Wśród nich są Lü (1979), Chao (1968:216-218), Zhang (2000:247), a także Zhu i Tian (2000,2:136). Li i Thompson (1981:37) wymieniają również prefiks 小 xiăo-. Sporadycznie spotyka się prefiks 大 dà- czy inne morfemy, które zgramatykalizowane są w tak niewielkim stopniu, iż można uznać je jedynie za quasi-prefiksy.

Niezwykle rzadki jest prefiks 阿 $\bar{a}$-. Jako jedyny przykład jego występowania we współczesnym ogólnonarodowym języku chińskim Chao (1968: 216) podaje wyraz 阿哥 $\bar{a} g \bar{e}$ 'starszy brat (tytuł używany na dworze qingowskim)'. Kratochvíl (1968:69) dodaje, że występuje on również w wyrazach będących bezpośrednimi zwrotami między krewnymi, np. 阿姨 āyí 'ciotka'. Ze znacznie częstszym jego użyciem mamy do czynienia w dialektach, np. kantońskim czy hakka ${ }^{6}$, gdzie pełni funkcję wyraźnie honoryfikatywną, o czym mówi Künstler (2000:183).

Dwa następne prefiksy właściwe, które wymieniają Li i Thompson (1981: 37), to prefiksy dodawane do liczebników. Są nimi 第 dì-, tworzący liczebniki porządkowe, np. 第六 diliù 'szósty', oraz 初 chū-, używany do określenia pierwszych dziesięciu dni miesiąca księżycowego, występujący przed liczebnikami od jednego do dziesięciu, np. 初二 chüèr 'drugi'.

Prefiksy 老 lăo- i 小 xiăo- wywodzą się od wyrazów 老 lăo 'stary' i 小 xiăo 'młody', 'mały'. Według Li i Thompson (1981:37) są typowymi przedrostkami dodawanymi do nazwisk w celu utworzenia przezwisk. W obydwu przypadkach sygnalizują dość zażyłe relacje, gdzie 老张 lăoZhāng '(Panie) Zhang' jest formą bardziej honoryfikatywną niż 小张 xiăoZhāng '(Panie) Zhang'. Ponadto prefiks 老 lăo- stoi przed liczebnikami od dwóch do dziesięciu, wskazując porządek wiekowy, np. wśród rodzeństwa, jak w 老二 lăoèr 'drugi z kolei', 老五 lăowú 'piąty z kolei', najstarszego określa się terminem 老大 lăodà, gdzie 大 dà oznacza 'duży'. Kratochvíl (1968:69) za najbardziej reprezentatywne wyrazy zawierające prefiks 老 lăo- uważa rzeczowniki 老师 lăoshī 'nauczyciel' i 老板 lăobăn 'szef' oraz niektóre nazwy zwierząt, np. 老虎 lăohŭ 'tygrys'.

\footnotetext{
${ }^{6}$ Dialekt hakka - jeden z siedmiu głównych dialektów chińskich, którego użytkownicy zamieszkują enklawy rozsiane na rozległym terenie Chin południowych (KüNSTLER, 2000 :297).
} 


\section{WYRAZY ZAWIERAJĄCE SUFIKS WŁAŚCIWY}

Liczba sufiksów właściwych - tzn. takich, które Künstler (2000:195) określa jako morfemy pozbawione swego etymologicznego tonu, które często wymawiane są w postaci zredukowanej oraz takie, których nie daje się oddzielić od poprzedzających ich rdzeni - jest stosunkowo niewielka. Taka definicja wyklucza bowiem wiele form sufiksopodobnych, które zachowują swój pierwotny ton, kwalifikując je do grupy quasi-sufiksów.

Pewna niewielka grupa sufiksów właściwych wymieniana jest zgodnie przez Chao (1968:228-244), Lü (1979), Li i Thompson (1981:39-45) oraz Zhu i Tian $(2000,2: 136)$. Podają oni pięć sufiksów rzeczownikowych: 儿 $-e r$, 子 $-z i$, 头 $-t o u$, 巴 $b a \mathrm{i}$ 们 -men. Niektórzy $\mathrm{z}$ nich wyliczają również sufiksy: 者 -zhè, 然 -rán oraz 乎 - hū, które - choć nie są pozbawione swego etymologicznego tonu - tworzą z rdzeniem nierozerwalny wyraz.

Sufiks 儿 -er to - jak podają Li i Thompson (1981:39-40) - jedyny asylabiczny sufiks w języku chińskim. Po przyłączeniu do poprzedzającej go sylaby zmienia ją w sylabę zakończoną dźwiękiem $-r$, jak w 鸟 niăo + 儿 er =鸟儿 niăor 'ptak', 根 gēn + 儿 $e r=$ 根儿 $g \bar{e} r$ 'korzeń'. Etymologicznie 儿 -er był rzeczownikowym sufiksem deminutywnym, czyli tworzył zdrobnienia rzeczowników. W dialekcie pekińskim asylabiczny sufiks 儿 - $r$ tworzy również: lokalizatory - jak 这儿 zhèr 'tutaj', określenia czasu - jak 今儿 jīr 'dziś', czasowniki - jak 玩儿 wánr 'bawić się' oraz klasyfikatory i jednostki miary - jak 片儿 piàr 'kromka', 'płatek' czy 本儿 běnr 'klasyfikator do książek i albumów'. Autorzy dodają, że sufiks 儿 - $r$, będący głównie sufiksem rzeczownikowym, swobodnie łączy się z rzeczownikami monosylabicznymi, do polisylabicznych dodawany jest rzadziej. W obrębie języków mandaryńskich częstotliwość jego występowania jest różna, przy czym najbardziej charakterystyczny jest dla dialektu pekińskiego.

Li i Thompson (1981:42) - podobnie jak Chao (1968:237) - uznają 子 $-z i$ za dawny sufiks deminutywny, który wywodzi się od wyrazu 子 ž o znaczeniu 'dziecko'. Jak pisze Künstler (2000:130-131), formacja 房子 fángzi, która pierwotnie oznaczała 'dziecko domu', tj. 'mały dom', tj. 'domek', z czasem przeszła w wyraz oznaczający tyle co 'dom', gdzie dawna struktura determinacyjna ${ }^{7}$ uległa całkowitemu zatarciu. Co ciekawe, Li i Thompson (1981:42-43) uważają, że obecnie nie jest to już sufiks produktywny, podczas gdy Kratochvíl (1968:68) określa go mianem najbardziej produktyw-

\footnotetext{
${ }^{7}$ Zob. część czwarta - struktury determinacyjne.
} 
nego. Sufiks 子 -zi jest komponentem dość licznej grupy rzeczowników. Li i Thompson (1981:42-43) podają takie przykłady, jak: 炉子 lúzi 'piec', 亭子 tíngzi 'pawilon' czy 盘子 pánzi 'talerz'.

Dwa wcześniej wymienione sufiksy 儿 -er i 子 $-z i$ to, według Chao (1968:228), najczęstsze sufiksy rzeczownikowe. Pozostałe, do których należą 头 -tou, 巴-ba i 们-men, występują już znacznie rzadziej.

Sufiks 头 -tou zazwyczaj jest komponentem rzeczowników, ale spotyka się go również w lokalizatorach. Li i Thompson (1981:42-44) podają wyrazy takie, jak: 骨头 gútou 'kość', 念头 niàntou 'idea', 'myśl' czy 前头 qiántou 'przed', jako przykłady łączenia się sufiksu 头 -tou z morfemami związanymi. Może być on również dołączony do monosylabicznych czasowników działania, jak w 那儿有什么看头? nàr yǒu shénme kàntou? 'co tam jest wartego obejrzenia?'. Autorzy twierdzą, że obecnie sufiks ten nie jest już produktywny.

Chao (1968:244) uważa, że sufiks 巴 -ba wywodzi się od morfemu o pierwotnym znaczeniu 'przywiązany', 'dołączony do'. Jest komponentem takich rzeczowników współczesnego języka chińskiego, jak 尾巴 wěiba 'ogon', 哑巴 yăba 'głuchoniemy' oraz 结巴 jiēba 'jąkała'.

Sufiks 们 -men tworzy liczbę mnogą. Według Li i Thompson (1981:40) jego użycie ogranicza się do zaimków osobowych, np. 我们 wǒmen 'my' oraz do polisylabicznych rzeczowników osobowych, np. 朋友们 péngyǒumen 'przyjaciele'. Przy tym dołączony do rzeczowników jest opcjonalny i ma funkcję emfatyczną. Redukcja tonów i zanik akcentu przyciskowego mają miejsce we wszystkich wymienionych przykładach, jednak w przypadku sufiksu 们 -men mamy również do czynienia ze wspomnianą wcześniej redukcją w wymowie. Zhu i Tian (2000,2:135) zauważają, że sufiks ten może być wprawdzie wymawiany jako pełna sylaba -men, częściej jednak wymawia się go w formie zredukowanej jedynie do fonemów ${ }^{8}-m n$ lub nawet samego $-m$.

Rzadsze sufiksy wymieniane przez Chao (1968:221) to: 者 -zhè, 然 -rán oraz 乎 $-h \bar{u}$. Rzeczownikowy sufiks osobowy 者 -zhě, choć występuje $\mathrm{w}$ wielu wyrazach, ma ograniczone użycie. Tworzy takie rzeczowniki, jak 译者 yìzhě 'tłumacz' czy 长者 zhăngzhě 'senior'. Sufiks 然 -rán tworzy przysłówki, np. 忽然 hūrán 'nagle', 当然 dāngrán 'oczywiście'. Sufiksem

\footnotetext{
${ }^{8}$ Fonem - jednostka systemu językowego o funkcji dystynktywnej, tj. służąca do rozróżniania znaczących elementów językowych - morfemów, niepodzielna na następujące po sobie elementy dystynktywne (EJO, $2003: 155)$.
} 
wywodzącym się z konstrukcji języka klasycznego 文言 wényán ${ }^{9}$ jest sufiks 乎 $-h \bar{u}$. Chao (1968:225) uważa, że bliskie tym konstrukcjom są wyrazy 近乎 jìnhu 'zbliżać się' i 在乎 zàihu 'troszczyć się', w których pierwotny ton afiksu uległ redukcji. Sufiks ten tworzy również przysłówki, np. 确乎 quèh $\bar{u}$ 'rzeczywiście' lub 几乎 jīhn 'prawie', w których 乎 $-h \bar{u}$ zachowało swój etymologiczny ton.

\section{WYRAZY ZAWIERAJĄCE KILKA SUFIKSÓW WŁAŚCIWYCH}

BĄDŹ PREFIKS I SUFIKS WŁAŚCIWY JEDNOCZEŚNIE

Zhu i Tian (2000:136) zwracają uwagę na ciekawe zjawisko przyłączania kilku sufiksów do monosylabicznego rdzenia. Tak zbudowany jest rzeczownik 石头儿 shitour 'klejnot', który składa się z wyrazu 石头 shitou 'kamień', zawierającego sufiks 头-tou, do którego następnie przyłączono sufiks 儿 -er. Możliwe jest również jednoczesne przyłączenie prefiksu i sufiksu, jak w wyrazie 老娘们儿 lăoniángmenr 'mężatka', w którym do semantemu 娘 niáng 'matka', 'kobieta' dołączono prefiks 老 lăo-, a także sufiksy 们 -men oraz 儿 -er.

\section{WYRAZY ZAWIERAJĄCE INFIKS}

Temat infiksów w języku chińskim jest zagadnieniem dość problematycznym. Definicje infiksów proponowane przez poszczególnych badaczy są bardzo odmienne. Zdarza się również, że kwestionowany bywa sam fakt istnienia infiksów we współczesnym języku chińskim.

Li i Thompson (1981:38) definiują infiks jako morfem związany, który po wstawieniu w wyraz już istniejący - tworzy nowy wyraz. Według Künstlera $(2000: 231)$ infiksów można dopatrywać się w potencjalnych formach czasowników rezultatywnych. Ich istnienie jednak zależy od tego, jak owe struktury zostaną zinterpretowane. Czasowniki rezultatywne zbudowane są z czasownika oraz elementu wyrażającego rezultat czynności, np. 打死 dăš̌ 'zabić' (dosł. uderzyć tak, że następuje śmierć). Potencjalne formy czasowników rezultatywnych tworzy się poprzez wstawienie morfemu 得 -de- lub 不 - bu- pomiędzy obydwa człony czasownika rezultatywnego, np. 打得死 dădeš̃ 'móc zabić' i 打不死 dăbusì 'nie móc zabić'. Według Künstlera, jeżeli czasowniki rezultatywne traktuje się jako wyrazy, wtedy morfemy 得

\footnotetext{
${ }^{9}$ Wenyan - klasyczny język chiński pisany.
} 
-de- oraz 不 -bu- można uznać za infiksy tworzące formy potencjalne tychże czasowników rezultatywnych. $\mathrm{Ku}$ takiemu ich traktowaniu skłaniają się właśnie Li i Thompson (1981:38-39).

Czasowniki rezultatywne można jednak potraktować również jako konstrukcje składniowe składające się z czasownika oraz jego postpozycyjnie umieszczonego określenia, czyli dopełnienia komplementywnego. Künstler (2000: 231) uważa, że w takiej sytuacji nie może być mowy o jakiejkolwiek infiksacji w języku chińskim. Tworzenie potencjalnych form czasowników rezultatywnych można bowiem rozpatrywać wyłącznie z punktu widzenia składni.

Chao (1968:257) uważa, że w języku chińskim można wyróżnić dwa infiksy, które występują w szczególnego rodzaju reduplikacjach. Są nimi: 里 $-l i-$, jak w 糊里糊涂 húlihútu 'zdezorientowany', 'otępiały', oraz 不 -bu-, jak w 酸不溜溜 suānbuliūliū 'kwaskowaty'.

\section{WYRAZY ZAWIERAJĄCE QUASI-AFIKS}

Wiele afiksów występujących we współczesnym języku chińskim powstało, jak twierdzi Zhang (2000:246), w wyniku gramatykalizacji morfemów leksykalnych. Zajdler (2005:66) definiuje gramatykalizację jako utratę przez element leksykalny pierwotnego znaczenia i przejście w morfem gramatyczny. Ponieważ stopień gramatykalizacji morfemów leksykalnych we współczesnym języku chińskim jest różny, Zhang (2000:247) uważa, że niektóre morfemy można uznać za formę pośrednią między morfemami rdzennymi a pobocznymi. Nie są to już rdzenie wyrazowe, ponieważ poddane zostały procesowi gramatykalizacji, ale nie można też powiedzieć, że całkowicie utraciły swoje znaczenie. Zhang uważa, że Lü (1979) określił morfemy podobne do afiksów mianem 类词缀 lèicizhuì, czyli 'quasi-afiksy'. Ponadto twierdzi, że obecność tego rodzaju morfemów jest dla języka chińskiego cechą dystynktywną.

Zhu i Tian $(2000,2: 136)$ dodają, że quasi-afiksy nie są na stałe związane z morfemami rdzennymi i często funkcjonują jako samodzielne wyrazy. Quasi-afiksy mogą łączyć się z monosylabicznymi rdzeniami, znacznie częściej jednak przyłączane są do wyrazów dwu- lub polisylabicznych, zwykle takich o wewnętrznej strukturze składniowej. Znaczenie quasi-afiksu często odbiega od pierwotnego lub podstawowego znaczenia morfemu, z którego się wywodzi, np. 派 -pài 'grupa', 'frakcja' w 无党派 wúdăngpài 'związek bezpartyjny' lub 式 -shì 'model', 'forma' w 英式 yingshì 'styl angielski'. 
Li i Thompson (1981:37-38) również stwierdzają istnienie pewnej grupy wyrazów, którą można uznać bądź za wyrazy o wewnętrznej strukturze składniowej $^{10}$, bądź za afiksacje. Wolą jednak traktować morfemy takie jak 可 kě, 难 nán czy 好 hăo jako prefiksy. Inni, nie dokonując wyboru między przynależnością takich morfemów do żadnej z dwóch wymienionych grup, przyjmują termin pseudo-afiksy lub quasi-afiksy, który po raz pierwszy zaproponowała czeska uczona Hermanová-Novotná (1969:6).

\section{WYRAZY ZAWIERAJĄCE QUASI-PREFIKS}

Te morfemy, które wielu badaczy nazywa quasi-prefiksami, Chao (1968: $211,214)$ określa jako morfemy wielofunkcyjne będące pierwszą sylabą wyrazu. Wyróżnia wśród nich formy honoryfikatywne i deprecjonujące w wyrazach będących bezpośrednimi zwrotami, np. 家 jiā- 'domowy' w 家父 jiāfù 'mój ojciec', 粉 bì- 'obdarty', 'nędzny' w 粫处 bichù 'mój dom rodzinny', 贱 jiàn- 'nędzny', 'uniżony' $\mathrm{w}$ 贱内 jiànnèi 'moja żona', 贵 guì- 'szacowny', 'wspaniały' w 贵姓 guixìng 'pańskie nazwisko'.

Chao (1968:214-216) zalicza do nich również prefiksy, które nazywa współczesnymi. Są to przetłumaczone na język chiński prefiksy występujące w innych językach. Należą do nich m.in. 单 dān- 'jedno-', 'mono-', jak w wyrazie 单细胞 dānxìbāo 'jednokomórkowy', 多 $d u \bar{o}-$ 'wielo-', 'multi-', jak w 多音节 duōyinjié 'polisylabiczny', 伪 wěi- 'pseudo-', jak w 伪政府 wěizhèngfǔ 'rząd marionetkowy', 无 wú- 'bez-', jak w 无线电 wúxiàndiàn 'bezprzewodowy', 亲 qīn- 'pro-', jak w 亲共 qìngòng 'prokomunistyczny', oraz 反 făn- 'anty-', 'kontr-', jak w 反间谍 fănjiàndié 'antyszpiegowski'.

Chen (2001:20-22) wymienia kilkanaście morfemów, które uważa za quasi-prefiksy, do najczęstszych zalicza m.in. 半 bàn- 'pół-', jak w wyrazie 半自动 bànzìdòng 'półautomatyczny', 超 chāo- 'super-', 'ultra-', jak w 超声波 chāoshēngbō 'fale ultradźwiękowe' czy 类 lèi- 'quasi-', 'para-', jak w 类词缀 lèicízhui 'quasi-afiks'.

\section{WYRAZY ZAWIERAJĄCE QUASI-SUFIKS}

Tak jak w przypadku prefiksów, wiele morfemów łączących się z morfemami rdzennymi umownie nazwano sufiksami, choć niezupełnie są one mor-

${ }^{10}$ Zob. część czwarta. 
femami pustymi leksykalnie. Wielofunkcyjne morfemy występujące na końcu wyrazu - jak Chao (1968:220) określał to, co dziś nazywamy quasisufiksami - mogą zachowywać swój pierwotny ton albo go tracić. Według Chao zaledwie w kilku przypadkach quasi-sufiksów pierwotny ton morfemu nie ulega redukcji. Takim jest np. quasi-sufiks 来 -lái, jak w wyrazie 原来 yuánlái 'pierwotnie'. Twierdzi on, że większość wymienionych przez niego morfemów, stając się quasi-sufiksami, traci swój etymologiczny ton i przyjmuje ton neutralny. Zawartość jednak współczesnych słowników języka chińskiego dowodzi czegoś wręcz odwrotnego. W słowniku《现代汉语词典》 Xiandai hanyu cidian (2001) (pol. Słownik współczesnego języka chińskiego) znajdują się te same wyrazy, którymi Chao (1968:222-225) popiera swoją tezę, większość z nich jednak - jak podaje słownik - nie utraciła swego etymologicznego tonu. Tak jest w przypadku 人 -rén 'człowiek' $\mathrm{w}$ wyrazie 工人 gōngrén 'pracownik', 是 -shì 'być' $\mathrm{w}$ 但是 dànshì 'ale' oraz 师 -shī 'mistrz', 'nauczyciel’ w 律师 lǜshī 'prawnik'. Niektóre morfemy pełniące funkcję quasi-sufiksów mogą w jednym wyrazie zachowywać swój ton, natomiast $\mathrm{w}$ innym go tracić. Takimi są np. morfemy: 性 -xìng 'temperament', 'natura', który w wyrazie 耐性 nàixìng 'cierpliwość' zachował swój ton, natomiast w wyrazie 记性 jìxing 'pamięć' utracił go, 气-qì (1) 'powietrze' lub (2) 'istota', który zachował ton w wyrazie 勇气 yǒngqi 'odwaga', a utracił go w wyrazie 脾气 píqi 'temperament', oraz 腾 -téng, wyrażający nagłą i powtarzającą się czynność, który w wyrazie 翻腾 fānténg 'wznosić się i opadać' zachował swój etymologiczny ton, natomiast utracił go w wyrazie 折腾 zhēteng 'przekręcać', 'przewracać'.

Do grupy wielofunkcyjnych morfemów występujących na końcu wyrazu, czyli do morfemów współcześnie zwanych quasi-sufiksami, Chao (1968: 225-228) włącza tak zwane sufiksy współczesne. Chodzi o sufiksy występujące w innych językach, które przetłumaczone zostały na język chiński. Należą do nich m.in. 化 -huà, jak w wyrazie 工业化 gōngyèhuà 'industrializacja', 论 -lùn, jak w 方法论 fāngfălùn 'metodologia', 学 -xué, jak $\mathrm{w}$ 化学 huàxué 'chemia', 家 -jiāa, jak w 天文家 tiānwénjiā 'astronom', 员 -yuán, jak w 教员 jiàoyuán 'instruktor'. W języku chińskim żaden z tych przetłumaczonych sufiksów nie występuje w tonie neutralnym.

Chen (2001:22-27) wymienia ponad pięćdziesiąt quasi-sufiksów, które uważa za często spotykane. Oprócz wyżej wymienionych są to m.in. 士 -shì 'uczony', jak w wyrazie 博士 bóshì 'doktor', 手 -shǒu (1) 'osoba uzdolniona' lub (2) 'ręka', jak w 㓣子手 guizishǒu 'kat', 工 -gōng 'praca', jak w 瓦工 wăgōng (1) 'tynkowanie' lub (2) 'kafelkowanie', 型 -xing 'model', 
'typ', jak w 重型 zhòngxíng (1) 'ciężki' lub (2) 'przemysłowy', czy 处 -chù 'miejsce', jak w wyrazie 问讯处 wènxùnchù 'informacja'.

Warto zaznaczyć, że zebranie wszystkich opracowań na temat quasi-afiksów, powstałych na przestrzeni ostatnich kilkudziesięciu lat na różnych kontynentach, nie dostarczy szczegółowej i wyczerpującej listy wszystkich morfemów, które można uznać za quasi-afiksy. Według Zhu i Tian (2000: 135) przyczyną tego jest fakt, że współczesny język chiński dopuszcza możliwość pojawienia się nowego quasi-afiksu w dowolnej chwili. Autorzy ilustrują to zjawisko przykładem nowo powstałego quasi-sufiksu 秀 -xiù, który jest fonetycznym zapożyczeniem angielskiego wyrazu show oznaczającego 'przedstawienie', 'pokaz'. W Hongkongu i na Tajwanie został on użyty do przetłumaczenia angielskiego pojęcia make show o znaczeniu 'robić pokaz'. Nowy chiński odpowiednik to 作秀 zuòxiù (dosł. robić show). Szybko powstały wyrazy typu 脱口秀 tuōkǒuxiù 'talk-show', 舞蹈秀 wǔdăoxiù 'popis taneczny', 脱衣秀 tuōyixxiù 'striptiz', 单人秀 dānrénxiù 'występ solo' czy 双人秀 shuāngrénxiù 'występ w duecie'. Stały się one popularne i przeniknęły do ogólnonarodowego języka chińskiego używanego na kontynencie. W ten oto sposób w języku chińskim pojawił się kolejny morfem, który uzyskał status quasi-afiksu.

\section{FORMACJE SEMANTEMOWE O WEWNĘTRZNEJ STRUKTURZE SKŁADNIOWEJ}

Według Künstlera (2000:9,127-128) przemiana, jaka zachodzi w języku chińskim od czasów archaicznych aż po dzień dzisiejszy, nazwana została przez Chmielewskiego ewolucją typologiczną języka chińskiego. Chmielewski scharakteryzował ją jako przejście od archaicznej morfologii wewnątrzsylabicznej, gdzie jednostkami morfologicznymi były fonemy, do współczesnej morfologii sylabicznej, gdzie takimi jednostkami są sylaby. Archaiczne wyrazy monosylabiczne zastąpione zostały dwusylabowymi grupami składniowymi, czyli syntagmami, które stopniowo ulegając leksykalizacji ${ }^{11}$, stawały się wyrazami. Inaczej mówiąc, archaiczne grupy składniowe stały się formacjami morfologicznymi, a stosunki między morfemami - dawnymi monosylabicznymi wyrazami - zachowały pierwotny charakter syntaktyczny.

${ }^{11}$ Leksykalizacja - utrata przez element leksykalny przejrzystości pierwotnej struktury wewnętrznej wyrazu (ZAJDLER, 2005 : 66). 
Künstler (2000:137) zwraca uwagę na fakt, że owa leksykalizacja grup składniowych odnosi się zarówno do stopniowego przekształcania się archaicznych dwusylabowych grup składniowych w wyrazy, jak również do nowo powstałych formacji, utworzonych zgodnie z regułami składni archaicznej, które następnie uległy leksykalizacji. Jego zdaniem wyrazy, które jako grupy składniowe występowały już w języku archaicznym, stanowią bardzo nieliczną grupę współczesnego słownictwa. Należą do nich m.in. 父母 fümǔ 'ojciec' + 'matka' = 'rodzice', 朋友 péngyou 'druh' + 'przyjaciel' = 'przyjaciel' czy 衣裳 yīshang 'górna szata' + 'dolna szata' = 'ubranie'. Większość wyrazów utworzona została według dawnego wzorca znacznie później, a nawet współcześnie. Monosylabiczne semantemy, czyli elementy znaczące, łączyły się ze sobą na zasadach składniowych, tworząc syntagmy i wyrazy o wewnętrznej strukturze składniowej. Jak twierdzi Künstler (2000: 231-232), ten typ wyrazów stanowi większość współczesnego słownictwa języka chińskiego. Najliczniejsze wśród nich są wyrazy dwusylabowe, składające się $\mathrm{z}$ dwóch członów znaczeniowych, czyli dwusemantemowe. Istnieją również wyrazy wielosylabowe, inaczej wielosemantemowe, które są jednak znacznie rzadsze.

Termin „wyraz” nie zawsze jest w języku chińskim terminem jednoznacznym, tak samo jest w przypadku terminu ,wyraz złożony”. Odmienne podejście prezentowane przez poszczególnych badaczy języka chińskiego spowodowało, że pojęcia te były rozumiane i definiowane na różne nierzadko wykluczające się - sposoby. Dodatkowego problemu dostarczyła terminologia, która okazała się mało jednoznaczna, gdyż dla różnych języków odnosiła się do różnych konstrukcji. Tak np. Chao (1968:359) określił wszystkie konstrukcje składające się z morfemów rdzennych połączonych ze sobą związkami typu składniowego terminem „compounds”. Jako jeden $z$ niewielu zwrócił uwagę na to, że pod tym terminem, który tłumaczy się jako „wyrazy złożone”, w przypadku języka chińskiego, kryją się nie tylko konstrukcje zbudowane z morfemów swobodnych, ale w szerszym rozumieniu zalicza się do nich również wyrazy powstałe z połączenia morfemów związanych. Według Zhu (1998:32) wszystkie takie wyrazy zbudowane $\mathrm{z}$ dwóch lub więcej morfemów rdzennych określa się w języku chińskim terminem 复合词 fühécí, który można przetłumaczyć jako 'wyrazy złożone' lub 'wyrazy zespolone'.

Oczywistym wydaje się fakt, że dalsze wyjaśnianie różnic w definiowaniu i terminologii wprowadziłoby jedynie niepotrzebne zamieszanie. W tym artykule omówione zostaną więc formacje semantemowe o wewnętrznej 
strukturze składniowej bez wyraźnego podziału na wyrazy i wyrazy złożone. Należy jednak zaznaczyć, że Künstler oraz Packard wyraźnie dzielą morfemy na związane, czyli takie, które występują wyłącznie w połączeniu z innymi morfemami, oraz swobodne, czyli takie, które mogą samodzielnie pełnić funkcje składniowe. Konstrukcję składającą się z dwóch rdzeni, z których przynajmniej jeden jest morfemem związanym, Packard (2000:81) określa jako „bound root word”, co można przetłumaczyć jako 'wyraz zawierający związany morfem rdzenny'. Künstler $(2000: 128,231)$ traktuje taką konstrukcję jako wyraz semantemowy. Natomiast „compound word” czy „wyrazem złożonym” nazywają oni konstrukcję zbudowaną z dwóch rdzeni będących morfemami swobodnymi, przy czym - według Künstlera konstrukcję taką nazywa się również syntagmą, czyli grupą składniową.

Künstler (2000:128-129) zaznacza, że tak przeprowadzony podział na wyrazy i wyrazy złożone w niektórych przypadkach nie jest wystarczający, w związku z czym konieczne jest odwołanie się do dodatkowych kryteriów, np. kryterium leksykalizacji. Zauważa on, że proces leksykalizacji nie zawsze przebiegał jednakowo. W niektórych przypadkach następował bardzo szybko, w innych zaś trwał wiekami. Niektóre syntagmy podlegają procesowi leksykalizacji do chwili obecnej. Wynikiem tego są obecne dziś w języku chińskim formy o różnym stopniu leksykalizacji, np. wpółzleksykalizowane lub wysoce zleksykalizowane, o czym mówi Zajdler (2005:66).

Według Künstlera (2000:129) wyznacznikami leksykalizacji mogą być np. kryterium nierozdzielności elementów składowych oraz kryterium nieodwracalności ich kolejności. Na ich podstawie daną konstrukcję można uznać za wyraz, jeśli jej elementy są nierozłączne, a szyk niezmienny. Kryteria te, choć precyzyjne, okazują się jednak mało pomocne, gdyż - jak uważa sam Künstler - mają zastosowanie jedynie w przypadku synonimicznych konstrukcji koordynacyjnych. Jeżeli więc np. konstrukcję koordynacyjną $\mathrm{AB}$ daje się rozdzielić na $\mathrm{A}$ oraz $\mathrm{B}$, to mówimy o koordynacyjnej grupie składniowej. W przypadku, gdy rozdzielenie takie jest niemożliwe, mamy do czynienia z wyrazem. Podobnie jest z nieodwracalnością szyku. Jeżeli koordynacja $\mathrm{AB}$ może występować również w formie $\mathrm{BA}$, to mamy do czynienia z koordynacyjną syntagmą. Jeśli zaś możliwa jest tylko jedna forma, to uważa się ją za wyraz o wewnętrznej strukturze koordynacyjnej.

Innymi wyznacznikami leksykalizacji są kryteria wymieniane przez Zhu (1998:33-34), a którymi posługiwał się również Chao (1968:362). Według nich z wyrazem mamy do czynienia w kilku następujących przypadkach. Po pierwsze, jeżeli struktury nie da się rozwinąć poprzez wstawienie partykuły 
的 de bez spowodowania zmiany jej znaczenia, np. 大车 dàchē 'wóz', 'furmanka', gdzie 大的车 dà de chē oznacza 'duży pojazd', oraz 金笔 jīnb 'wieczne pióro ze złotą skuwką', gdzie 金的笔 jīn de b̌̌ oznacza 'złote pióro'. Warto zauważyć, że kryterium to dotyczy wyłącznie struktur determinacyjnych. Po drugie, o wyrazie mówimy wtedy, gdy jego znaczenie uległo rozszerzeniu lub stało się całkowicie metaforyczne. Innymi słowy, z wyrazem mamy do czynienia wtedy, gdy jego znaczenie nie daje się wywnioskować ze znaczenia poszczególnych semantemów, np. 大方 dàfang 'hojny' (dosł. duży i prawy) czy 龙头 lóngtóu 'kurek', 'kran' (dosł. głowa smoka). Należy przy tym dodać, że owo metaforyczne rozszerzenie znaczenia przybiera różne natężenie. Li i Thompson (1981:46-48) mówią o kilku stopniach metaforyzacji, pomiędzy którymi nie da się wyróżnić formalnych granic. Ilustrują to przykładami wyrazów o słabym, średnim i wysokim stopniu metaforyzacji, odpowiednio: 满足 mănzú 'zadowolony' (dosł. pełny i dostateczny), 天气 tiānqi 'pogoda' (dosł. oddech nieba), 薪水 xīnshǔi 'pensja' (dosł. paliwo i woda). Zhu (1998:33-34) twierdzi jednak, że kryterium to nie ma powszechnego zastosowania, gdyż w większości przypadków znaczenie wyrazu łatwo można wywnioskować ze znaczenia poszczególnych członów, np. 鸭蛋 yādàn 'kaczka' + 'jajo' = 'kacze jajo'. Po trzecie, dodatkowym wyznacznikiem leksykalizacji może być występowanie sylaby końcowej $\mathrm{w}$ tonie neutralnym, np. 买卖 măimai 'handel', 火烧 huŏshao 'pieczony placek pszenny' czy 打手 dăshou 'zbir'. Trzeba jednak zaznaczyć, że kryterium to ma zastosowanie jedynie dla północnej odmiany języka ogólnonarodowego, w której redukcja tonów nie jest tak powszechna, jak w odmianach południowych.

Wszystkie wymienione kryteria, będące wyznacznikami leksykalizacji, mają ograniczone zastosowanie. Nie można stwierdzić, że wyodrębniono jakiekolwiek kryterium, które byłoby wystarczające do rozstrzygnięcia wszystkich przypadków. Jedne podlegają ograniczeniom strukturalnym, np. pasują wyłącznie do struktur determinacyjnych bądź koordynacyjnych, inne uwarunkowane są semantycznie, gdyż można je zastosować np. tylko do wyrażeń o znaczeniu przenośnym. Niektóre kryteria częściowo pokrywają się ze sobą i są wspólne dla różnych grup wyrazów.

Ciekawe jest spostrzeżenie Li i Thompson (1981:46), którzy za wyraz uznają takie jednostki, które mają cechy pojedynczych wyrazów. Tak np. wyrazem jest według nich 开关 kāiguān 'włączać' + 'wyłączać' = 'przełącznik'. Ma on bowiem cechę pojedynczego wyrazu, gdyż odnosi się do pojedynczego przedmiotu, tu: przełącznika. W takich przypadkach konstrukcja, 
nazywająca konkretny przedmiot bądź konkretne pojęcie uważana jest za zleksykalizowany wyraz.

W dalszej części artykułu omówione zostaną różne konstrukcje semantemowe zbudowane z morfemów rdzennych. Pośród nich znajdą się zarówno wyrazy zawierające przynajmniej jeden związany morfem rdzenny, jak również zleksykalizowane syntagmy, zwane inaczej wyrazami złożonymi, na których budowę składają się morfemy swobodne.

\section{TYPY STRUKTUR SKŁADNIOWYCH}

Künstler (2000:59-61) podaje, że najbardziej szczegółowy system klasyfikacji stosunków składniowych, opracowany dla potrzeb analizy dwuelementowych syntagm, które stały się późniejszymi dwusylabowymi wyrazami semantemowymi, stworzony został przez Chmielewskiego. Chmielewski wyróżnił osiem następujących typów stosunków składniowych: koordynacja czyli A i B, determinacja - A określa B, rekcja - A rządzi B, dyrekcja A ukierunkowuje B (dotyczy stosunku między czasownikiem pomocniczym lub modalnym a czasownikiem głównym), introdukcja - A wprowadza B (dotyczy stosunku rezultatywnego), subiekcja - A jest podmiotem, a B orzeczeniem, predykacja - A jest orzeczeniem, a B podmiotem, ekspozycja A jest eksponowane, a B jest odnoszącym się do niego komentarzem.

Tradycyjne klasyfikacje stosunków składniowych, występujących między morfemami rdzennymi w obrębie wyrazu, są mniej rozbudowane. Chao (1968: 368-480), Hu (1995:213) oraz Zhu (1998:32-33) wyróżniają pięć typów wyrazów o wewnętrznej strukturze składniowej. Należą do nich: wyrazy o strukturze podmiotowo-orzeczeniowej (陈述式 chénshùshì lub 主谓式 zhǔwèishi), wyrazy o strukturze koordynacyjnej (联合式 liánhéshi), subordynacje, czyli wyrazy określane przez innych jako determinacje (附加式 füjiāshì lub 偏正式 piānzhèngshi), wyrazy o strukturze czasownikowo-dopełnieniowej, czyli rekcje (支配式 zhīpèishì lub 述宾式 shùbinshi) oraz struktury komplementywne, czyli wyrazy złożone z czasownika i dopełnienia komplementywnego (补充式 bǔchōngshì lub 述补式 shùbǔshì).

Poniżej formacje semantemowe zostaną omówione w ramach pięciu wymienionych typów strukturalnych. Przyjrzymy się więc kolejno strukturom podmiotowo-orzeczeniowym, koordynacyjnym, determinacyjnym, rekcyjnym oraz komplementywnym. Jako ostatnie zostaną omówione formacje wielosemantemowe zawierające spiętrzone struktury składniowe. 


\section{STRUKTURY PODMIOTOWO-ORZECZENIOWE}

Za najrzadsze pośród wyrazów semantemowych o wewnętrznej budowie typu składniowego uważa się wyrazy o strukturze podmiotowo-orzeczeniowej. Li i Thompson (1981:70) definiują je jako wyrazy zbudowane $\mathrm{z}$ dwu komponentów, z których jeden pełni funkcję podmiotu, a drugi orzeczenia. Relacja zachodząca między tymi komponentami zwana jest predykacją. Hu (1995: 215) dodaje, że relację łączącą te dwa komponenty można nazwać orzekaniem lub oznajmianiem. Pierwszy człon jest tym, o którym się coś orzeka, natomiast drugi jest tym, który oznajmia. Według Li i Thompson (1981:72) większość wyrazów o strukturze podmiotowo-orzeczeniowej to przymiotniki występujące $\mathrm{w}$ funkcji predykatywnej ${ }^{12}$. Zbudowane są one $\mathrm{z}$ rzeczownika w funkcji podmiotu i przymiotnika pełniącego funkcję orzeczenia, czyli predykatywu. Do najbardziej znanych wyrazów tego typu Künstler (2000: 135-136) zalicza 胆大 dăndà 'odważny' (dosł. żółć jest duża), 胆小 dănxiăo 'tchórzliwy' (dosł. żółć jest mała) i 胆寒 dănhán 'przerażony' (dosł. żółć jest zimna). Wśród wyrazów o strukturze podmiotowo-orzeczeniowej są również rzeczowniki. Chao (1968:368) i Zhu (1998:32) wymieniają chińskie nazwy pór roku, np. 冬至 dōngzhì 'przesilenie zimowe' (dosł. zima przychodzi), 霜降 shuāngjiàng 'odejście mrozów' (dosł. mróz opada) lub innych zjawisk naturalnych, np. 地震 dìzhèn 'trzęsienie ziemi' (dosł. ziemia się trzęsie). Wśród tego typu wyrazów znajdują się również czasowniki oraz spójniki. Chao (1968:369-371) podaje np. 声张 shēngzhāng 'rozgłaszać' (dosł. dźwięk się rozprzestrzenia) oraz lìrú 例如 'na przykład' (dosł. przykład jest taki jak).

\section{STRUKTURY KOORDYNACYJNE}

Badacze tacy jak Hu (1995:213-214) oraz Li i Thompson $(1981: 54,81)$ pod względem semantycznym dzielą wyrazy o strukturze koordynacyjnej na koordynacje synonimiczne, czyli takie, których komponenty mają znaczenie bliskoznaczne, np. 语言 yǔyán 'język' + 'mowa' = 'język', 盗贼 dăozéi 'rabuś' + 'złodziej' = 'złodziej’, oraz na koordynacje antonimiczne, czyli takie, których komponenty mają znaczenie przeciwstawne, np. 横坚 héngshù 'poziomy' + 'pionowy' = 'mimo wszystko', 大小 dàxiăo 'duży' + 'mały' =

${ }^{12}$ Funkcja predykatywna - funkcja orzeczenia, którą w zdaniu mogą spełniać zarówno czasowniki, jak i przymiotniki (ZAJDLER, 2005:20). 
'rozmiar'. Połączenia antonimiczne tworzą często terminy abstrakcyjne. Künstler (2000:134) wyróżnia ponadto koordynacje stojące na pograniczu synonimii i antonimii, które Li i Thompson (1981:54) określają jako te, których komponenty należą do tej samej klasy semantycznej, np. 父母 fùmú 'ojciec' + 'matka' = 'rodzice', 花木 huāmù 'kwiat' + 'drzewo' = 'roślinność'.

Kratochvíl (1968:75) twierdzi, że pod względem strukturalnym wyrazy o budowie koordynacyjnej są odzwierciedleniem koordynacyjnych struktur

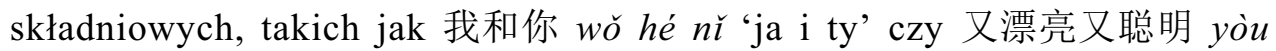
piàoliang yòu cóngmíng 'zarówno piękna, jak i mądra'. Wyrazy zbudowane koordynacyjnie należą do różnych kategorii gramatycznych. Zhu (1998:33) wymienia koordynacyjnie zbudowane rzeczowniki, np. 法律 fălù 'prawo' + 'zasady = 'prawo', czasowniki, np. 安慰 ānwèi 'uspokajać' + 'pocieszać' = 'pocieszać', przymiotniki, np. 奇怪 qíguài 'osobliwy' + 'dziwny' = 'dziwny', przysłówki, np. 根本 gēnběn 'korzeń' + 'korzeń' = 'zupełnie', a także przyimki, np. 自从 zìcóng ' $\mathrm{z}$ ' + 'od' = 'od', oraz spójniki, np. 而且 érqiě 'i' + 'ponadto' = 'oraz'.

W obrębie tych kategorii Chao (1968:372-374) przeprowadza szczegółowy podział wyrazów w zależności od kategorii gramatycznej, do której należą poszczególne semantemy. Tak więc wśród koordynacyjnie zbudowanych rzeczowników wyróżnia zbudowane $\mathrm{z}$ dwóch rzeczowników, np. 车马 chēmă 'wozy' + 'konie' = 'ruch uliczny', rzeczowniki zbudowane z dwóch jednostek miary, np. 条件 tiáojiàn 'artykuły' + 'rzeczy' = 'warunki', rzeczowniki zbudowane z dwóch przymiotników, np. 烦恼 fánnăo 'zirytowany' + 'zły' = 'utrapienie', oraz rzeczowniki składające się z dwóch czasowników, np. 教授 jiàoshòu 'uczyć' + 'przekazywać' = 'profesor'.

Koordynacyjnie zbudowane przymiotniki mogą składać się z: dwóch przymiotników, np. 懒惰 lănduò 'leniwy' + 'niemrawy' = 'leniwy', dwóch rzeczowników, np. 矛盾 máodùn 'włócznia' + 'tarcza' = 'sprzeczny', albo dwóch czasowników, np. 保守 băoshǒu 'zachowywać' + 'pilnować' = 'konserwatywny'.

Wśród czasowników o strukturze koordynacyjnej znajdują się głównie te zbudowane z dwóch czasowników, np. 失败 shībài 'stracić' + 'zostać pokonanym' = 'odnieść porażkę'. Jeśli natomiast komponenty nie są czasownikami, to wyraz taki należy zazwyczaj do kilku kategorii gramatycznych jednocześnie. Wyraz 满足 mănzú, składający się z dwóch przymiotników 满 măn 'pełny' oraz 足 zú 'dostateczny', może być czasownikiem o znaczeniu 'zadowalać' bądź przymiotnikiem 'zadowolony'. Wyraz 牺牲 xīshēng, utworzony z dwóch rzeczowników: 牺 $x \bar{l}$ 'zwierzę ofiarne' i 牲 shēng 'zwierzę 
domowe', występuje zarówno jako czasownik 'składać w ofierze', jak i rzeczownik 'ofiara'.

Przysłówki o budowie koordynacyjnej mogą być zbudowane na wiele sposobów. Oprócz tych złożonych z dwóch przysłówków, np. 互相 hùxiāng 'nawzajem' + 'wzajemnie' = 'nawzajem', istnieją również złożone z dwóch czasowników, np. 始终 shǐzhōng 'zaczynać' + 'kończyć' = 'ostatecznie', złożone z dwóch rzeczowników, np. 日夜 rìyè 'dzień' + 'noc' = 'przez całą dobę', a także złożone $\mathrm{z}$ dwóch liczebników, np. 千万 qiānwàn 'tysiąc' + 'dziesięć tysięcy' = 'absolutnie'.

\section{STRUKTURY DETERMINACYJNE}

Künstler (2000:61) dzieli determinacje na pre- i postpozycyjne. Determinacje prepozycyjne to takie, w których znaczenie pierwszego morfemu jest określeniem lub zawężeniem znaczenia drugiego morfemu. Relacja taka przedstawia się jako: wyraz określający - wyraz określany. Determinacje postpozycyjne są niejako odwrotnością determinacji prepozycyjnych, znaczenie bowiem drugiego morfemu jest określeniem bądź zawężeniem znaczenia morfemu pierwszego. Relacja taka przedstawia się jako: wyraz określany - wyraz określający. Semantem stojący na pozycji wyrazu określanego nazwany jest przez Künstlera jądrem determinacji. Determinacje prepozycyjne, np. 南湖 nánhú 'południowe jezioro' i 北伐 běifá 'północna wyprawa', mają charakter atrybutywny. Determinacje postpozycyjne, np. 湖南 húnán 'na południe od jeziora' i 伐北 fáběi 'wyprawić się na północ', mają charakter kierunkowy.

Zdaniem Hu (1995:214) zdecydowana większość wyrazów o strukturze determinacyjnej to determinacje prepozycyjne, czyli takie, w których semantem pierwszy określa semantem drugi. Poniżej terminem determinacje będą więc określane wyłącznie determinacje prepozycyjne. Według Hu określenie bądź zawężenie znaczenia może dotyczyć: właściwości, np. 红旗 hóngqi 'czerwony sztandar', przynależności, np. 驼毛 tuómáo 'wełna wielbłądzia', stanu, np. 狂欢 kuánghuān 'hulać' (dosł. szaleńczo się bawić), sposobu, np. 单干 dān'gàn 'pracować w pojedynkę', ilości, np. 四季 sìjì 'cztery pory roku', stopnia, np. 深入 shēnrù 'zagłębiać się' (dosł. głęboko wchodzić), lub czasu, np. 春耕 chūngēng 'wiosenna orka'.

Struktury determinacyjne Künstler (2000:25,137-138) nazywa inaczej peryfrastycznymi, czyli opisowymi. Do najstarszych wyrazów zbudowanych na zasadzie peryfrazy należą np. 天下 tiānxià 'świat' (dosł. to, co jest pod 
niebem) czy 渔夫 yúfū 'rybak' (dosł. mąż, który łowi ryby). Współcześnie większość słownictwa naukowego i technicznego tworzona jest na zasadach peryfrazy. Künstler twierdzi, że to właśnie peryfrastyczny charakter neologizmów przyczynił się do zdecydowanej przewagi struktur determinacyjnych we współczesnym języku chińskim.

Pośród wyrazów zbudowanych determinacyjnie Zhu (1998:32-33) wyróżnia: rzeczowniki, np. 飞机 fēijī 'samolot' (dosł. latająca maszyna), czasowniki, np. 重视 zhòngshì 'szanować' (dosł. z poważaniem patrzeć), przymiotniki, np. 冰凉 bingliáng 'lodowaty' (dosł. lodowato zimny), przysłówki, np. 未免 wèimiăn 'nieuchronnie' (dosł. jeszcze nie unikać), oraz spójniki, np. 不但 búdàn 'nie tylko' (dosł. nie jedynie).

Ponieważ w większości przypadków struktury determinacyjne należą do tej samej kategorii gramatycznej co jądra determinacji, Chao (1968:381415) przeprowadza ich podział według kategorii, do których należą jądra determinacji. Wyróżnia on m.in. wyrazy z jądrem rzeczownikowym, wyrazy zawierające determinant ${ }^{13}$ lub jednostkę miary, wyrazy zawierające lokalizator, wyrazy z jądrem czasownikowym, wyrazy z jądrem przymiotnikowym a także inne struktury determinacyjne.

Wśród wyrazów z jądrem rzeczownikowym wyróżnia wyrazy składające się z dwóch rzeczowników, np. 冬天 dōngtiān 'zima' (dosł. zimowy dzień), wyrazy składające się z przymiotnika i rzeczownika, np. 香料 xiāngliào 'przyprawa' (dosł. pachnący materiał), 虚心 xūxīn 'skromny' (dosł. pusty umysł) lub 强调 qiángdiào 'podkreślać' (dosł. mocny akcent), wyrazy składające się z czasownika i rzeczownika, np. 观众 guānzhòng 'widownia' (dosł. oglądający tłum), 委员 wěiyuán 'członek komitetu' (dosł. wydelegowany członek) lub 卧车 wòchē ‘wagon sypialny’ (dosł. pojazd, w którym się śpi).

Wyrazy zawierające determinant lub jednostkę miary to m.in. wyrazy zbudowane z determinanta i rzeczownika, np. 一块 yīkuài 'razem' (dosł. jeden kawałek), 一口钟 yīkǒuzhǒng 'peleryna' (dosł. jeden otwór dzwonu), oraz wyrazy zbudowane $\mathrm{z}$ rzeczownika i jednostki miary, np. 书本 shūběn 'książki' (dosł. tomy książek).

Wyrazem o wewnętrznej strukturze determinacyjnej, zawierającym lokalizator, jest np. 海外 hăiwài 'zagraniczny' (dosł. poza morzem).

Wyrazy z jądrem czasownikowym Chao dzieli na: zawierające rzeczownik, np. 步行 bùxíng 'iść na piechotę' (dosł. krokami iść), zawierające przymiotnik, np. 轻视 qīngshì 'pogardzać' (dosł. lekko spoglądać), oraz

${ }^{13}$ Determinant - określnik, człon określający (EJO, 2003 : 405). 
zawierające przysłówek, np. 楞要 lèngyào 'nalegać' (dosł. definitywnie domagać się).

Wśród wyrazów z jądrem przymiotnikowym wyróżnia zawierające rzeczownik, np. 火急 huǒji 'pilny' (dosł. nagły jak ogień), zawierające czasownik, np. 透明 tòumíng 'prześwitujący' (dosł. jasny aż prześwituje), a także zawierające przysłówek, np. 自满 zimăn 'zadowolony z siebie' (dosł. samemu pełny).

Chao podaje również przykłady innych, rzadziej spotykanych, wyrazów o strukturze determinacyjnej, np. 若使 ruòshǐ 'jeśli' (dosł. jeśli pozwalać), 想必 xiăngbì ‘najprawdopodobniej’ (rozważywszy koniecznie) czy 老早 lăozăo 'dawno temu' (bardzo wcześnie).

\section{STRUKTURY REKCYJNE}

Wyrazy o wewnętrznej strukturze składniowej rekcyjnej, czyli czasownikowo-dopełnieniowej, powstały - jak twierdzą Li i Thompson (1981:80) - z pierwotnych fraz składających się z czasownika i jego dopełnienia. Frazy te z czasem uległy procesowi leksykalizacji i stały się wyrazami. Hu (1995: 215) określa relację między dwoma morfemami takich wyrazów jako związek rządu, w którym pierwszy morfem - czasownik rządzi drugim - rządzi dopełnieniem. Künstler (2000:179) zauważa, że rekcyjne grupy składniowe leksykalizowały się stosunkowo rzadko. Do najwcześniej zleksykalizowanych należą wyrazy nierozkładalne, np. 倾心 qingxīn 'skłaniać' + 'serce' = 'podziwiać z całego serca'. Natomiast późniejsze struktury rekcyjne często zbudowane są z elementów swobodnych, które można rozdzielić, np. 说话 shuōhuà 'mówić' + 'słowa' = 'mówić', jak w 他说什么话? tā shuō shénme huà? 'co on mówi?' (dosł. jakie słowa on mówi?).

Wśród wyrazów o budowie rekcyjnej Zhu (1998:32) wyróżnia: rzeczowniki, np. 防风 fángfēng 'chronić przed' + 'wiatr' = 'falochron', czasowniki, np. 出版 chūbăn 'wpuszczać' + 'matryca' = 'publikować', przymiotniki, np. 卫生 wèishēng 'ochraniać' + 'życie' = 'higieniczny' oraz przysłówki, np. 到底 dàodì 'osiągnąć' + 'dno' = 'w końcu'.

Li i Thompson (1981:76-79) stwierdzają, że znaczna część wyrazów o strukturze czasownikowo-dopełnieniowej funkcjonuje jako czasowniki. Zdecydowana ich większość to czasowniki nieprzechodnie, czyli takie, które nie przyjmują dopełnienia po czasowniku, np. 开刀 kāidāo 'otwierać' + 'nóż' = 'operować' lub 照相 zhàoxiàng 'odbijać' + 'obraz' = 'fotografować'. Czasowniki przechodnie, czyli przyjmujące dopełnienie, to np. 关心 guānxīn 
'angażować' + 'serce' = 'troszczyć się' lub 怀疑 huáiyí 'żywić' + 'wątpliwości' = 'wątpić'. Künstler $(2000: 136,232)$ wymienia ciekawą grupę czasowników o strukturze rekcyjnej, a mianowicie czasowniki z tak zwanymi dopełnieniami pustymi, czyli takimi, które pozbawione są znaczenia, a służą jedynie uzupełnieniu struktur do dwu sylab. Należą do nich np. 说话 shuōhuà 'mówić' + 'słowa' = 'mówić' i 写字 xiězì 'pisać' + 'znaki' = 'pisać'.

Według Chao (1968:419) rzeczowniki o strukturze czasownikowo-dopełnieniowej najczęściej składają się z czasownika oraz rzeczownika i zwykle mają znaczenie 'tego, który powiązany jest z czynnością wyrażoną za pomocą czasownika i jego dopełnienia', np. 领事 lǐngshi 'prowadzić' + 'spra$\mathrm{wa}^{\prime}$ ' ' 'konsul', 行政 xíngzhèng 'realizować' + 'polityka' = 'administracja' lub 代数 dàishù 'zastępować' + 'liczba' = 'algebra'.

Pośród wyrazów o strukturze rekcyjnej Chao (1968:423) wymienia również wykrzykniki, np. 劳驾 láojià 'zadawać trud', 'zajmować' + 'powóz' = 'przepraszam' oraz 费心 fèixīn 'zużywać' + 'serce' = 'przepraszam, czy można prosić'.

Künstler (2000:136) twierdzi, że prawie zawsze możliwa jest inna interpretacja struktur złożonych $\mathrm{z}$ czasownika i rzeczownika $\mathrm{w}$ funkcji dopełnienia lub czasownika i rzeczownika, który z punktu widzenia struktury mógłby być jego dopełnieniem. Uważa on, że czasownik monosylabiczny może zostać użyty atrybutywnie jako określenie rzeczownika, a powstała w ten sposób struktura może lub musi być traktowana jako determinacja. Konstrukcja złożona z czasownika 飞fēe 'lecieć' i rzeczownika 乌 niăo 'ptak' musi być rozpatrywana jako determinacja 'latający ptak', tak samo jest w przypadku wyrazu 能人 néngrén 'człowiek utalentowany' (dosł. potrafiący człowiek). Niektóre wyrazy, np. 炒菜 chăocài oraz 炒肉 chăoròu, są zarówno strukturami determinacyjnymi oznaczającymi 'warzywa smażone' i 'mięso smażone', jak też strukturami rekcyjnymi o znaczeniu 'smażyć warzywa' i 'smażyć mięso'.

\section{STRUKTURY KOMPLEMENTYWNE}

Wszystkie konstrukcje o wewnętrznej strukturze składniowej komplementywnej, inaczej zwane czasownikami komplementywnymi, to konstrukcje złożone z czasownika i dopełnienia komplementywnego, czyli uzupełnienia. Ponieważ konstrukcje te składają się wyłącznie z morfemów swobodnych, Zajdler (2005:55-56) nazywa je syntagmami, czyli wyrazami złożonymi. Dopełnienie komplementywne w takiej syntagmie sygnalizuje posze- 
rzenie znaczenia danego czasownika. Tradycyjnie konstrukcje takie otrzymały miano czasowników rezultatywnych, gdyż owo poszerzenie znaczenia w głównej mierze dotyczyło rezultatu czynności. W wyniku wnikliwszych badań w grupie czasowników rezultatywnych wyróżniono dwa zasadnicze rodzaje struktur. Syntagmy ściśle określające czynność i zaistniały w jej wyniku rezultat określono jako czasowniki rezultatywne, które Zajdler precyzyjniej nazywa rezultatywnymi syntagmami czasownikowo-dopełnieniowymi lub syntagmami rezultatywnymi. Natomiast syntagmy, których dopełnienie komplementywne precyzuje kierunek, a nie skutek danej czynności, określa się mianem czasowników kierunkowych, a dokładniej - kierunkowymi syntagmami czasownikowo-dopełnieniowymi lub syntagmami kierunkowymi. Pośród syntagm kierunkowych Zajdler (2005:64-67,79) wyodrębnia syntagmy pozornie kierunkowe, w których komplementywne dopełnienie kierunkowe $\mathrm{w}$ wyniku procesów gramatykalizacji oraz leksykalizacji utraciło dosłowną kierunkowość, strukturalnie zachowując jednak charakter syntagmy kierunkowej. Jako przykład syntagmy pozornie kierunkowej podaje 说出来 shuōchūlái 'mówić' + 'na zewnątrz' + 'wyjść w kierunku mówiącego' = 'wypowiedzieć' lub 想出来 xiăngchūlái 'myśleć' + 'na zewnątrz' + 'wyjść w kierunku mówiącego' = 'wymyślić'.

Ponadto Zajdler wyszczególnia również syntagmy, których nie można jednoznacznie zaliczyć ani do syntagm kierunkowych, ani rezultatywnych. Są to tak zwane syntagmy dwuznaczne, czyli takie, których dopełnienie komplementywne może wskazywać zarówno na rezultat, jak i kierunek czynności. Do takich należy np. 走过 zǒuguò 'iść' + 'minąć' = 'minąć idąc' oraz 买得起 măideq oznaczający 'w górę' nabrał znaczenia 'być w stanie coś nabyć'.

Zdaniem Künstlera (2000:161) struktury komplementywne wywodzą się z pierwotnych struktur koordynacyjnych, które ulegając procesom leksykalizacji i gramatykalizacji przekształcały się w konstrukcje rezultatywne bądź kierunkowe, w których drugi czasownik zaczął pełnić funkcję dopełnienia komplementywnego. Do najwcześniejszych struktur tego typu zalicza on syntagmę kierunkową 避去 bìqù 'uciec' + 'oddalić się w kierunku przeciwnym do mówiącego' = 'uciec w kierunku przeciwnym do mówiącego' oraz syntagmę rezultatywną 打破 dăpò 'uderzyć' + 'złamać' = 'uderzyć tak, że coś zostało złamane'. Pod względem strukturalnym Künstler określa konstrukcje komplementywne jako rodzaj determinacji postpozycyjnych, w których zarówno dopełnienie rezultatywne, jak i kierunkowe, pełnią funkcję postpozycyjnego określenia czasownika, wskazującego na rezultat bądź kierunek czynności. 
Syntagmy kierunkowe to czasowniki zbudowane z czasownika i komplementywnego dopełnienia kierunkowego, w którego roli występuje prosty bądź złożony czasownik wyrażający kierunek. Pośród czasowników prostych Künstler (2000:235) wymienia np. 来 lái 'poruszać się w kierunku osoby mówiącej' oraz 去 qù 'poruszać się $\mathrm{w}$ kierunku przeciwnym niż osoba mówiąca'. W połączeniu z czasownikiem 近 jìn 'wchodzić' tworzą syntagmy kierunkowe, takie jak 进来 jìnlái 'wchodzić w kierunku osoby mówiącej' oraz 进去 jìnqù 'wchodzić $\mathrm{w}$ kierunku przeciwnym do osoby mówiącej'. W złożonych czasownikach określających kierunek często występują czasowniki proste 上 shàng 'poruszać się $\mathrm{w}$ górę' i 下 xià 'poruszać się $\mathrm{w}$ dół'. $\mathrm{Z}$ czasownikiem 跑 păo 'biec' tworzą całą gamę czasowników bardzo precyzyjnie wskazujących kierunek czynności. Czasownik 跑上 păoshàng ‘biec pod górę’ można rozbudować do 跑上来 păoshànglái 'biec pod górę w kierunku osoby mówiącej' oraz 跑上去 păoshàngqù 'biec pod górę w kierunku przeciwnym do osoby mówiącej'. Podobnie czasownik 跑下 păoxià 'biec w dół' można rozszerzyć do 跑下来 păoxiàlái 'biec w dół w kierunku osoby mówiącej' oraz 跑下去 păoxiàqù ‘biec w dół w kierunku przeciwnym do osoby mówiącej'.

Syntagmy rezultatywne to czasowniki zbudowane z czasownika oraz komplementywnego dopełnienia rezultatywnego, które Zajdler (2005:90-92) określa również mianem postwerbu, czyli elementu występującego postpozycyjnie w stosunku do czasownika. W funkcji postwerbu mogą występować zarówno czasowniki, jak i przymiotniki pełniące funkcję predykatywną. Semantycznie postwerby sygnalizują rezultat, który powstaje w wyniku czynności wyrażonej przez czasownik znajdujący się na pozycji pierwszej. Ze względu na znaczenie Zajdler dzieli postwerby na pięć grup. Postwerby zmiany stanu sygnalizują zmianę z jednego stanu na inny, np. 坏 huài 'zły', 'zepsuty' w wyrazie 弄坏 nònghuài 'sprawić' + 'zepsuty' = 'zniszczyć', 成 chéng 'stać się’ $\mathrm{w}$ 化成 huàchéng 'stopnieć' + 'zmienić się' = 'roztopić się'. Postwerby jakości dotyczą cech fizycznych, np. 大 dà 'duży' w 长大 zhăngdà 'rosnąć' + 'duży' = 'urosnąć', 白 bái 'biały' $\mathrm{w}$ 洗白 xǐbái 'prać' + 'biały' = 'wyprać do czysta'. Postwerby mentalne sygnalizują procesy umysłowe i konceptualne, np. 见jiàn 'zauważyć' w 看见 kànjiàn 'patrzeć' + 'zauważyć' = 'dostrzec', 懂 dǒng 'rozumieć' w 听懂 tīngdǒng 'słuchać' + 'rozumieć' = 'usłyszawszy zrozumieć'. Postwerby fazowe sygnalizują stan zaawansowania czynności, np. 好 hăo 'dobrze ukończony' w 看好 kànhăo 'patrzeć' + 'dobrze' = 'przypatrzyć się', 'dobrze ocenić', 到 dào 'dotrzeć', 'osiągnąć cel' $\mathrm{w}$ 找到 zhăodào 'szukać' + 'osiągnąć' = 'znaleźć'. Postwerby 
wykończenia i zużycia sygnalizują rozszerzenie czynności i jej intensyfikację, np. 光 guāng 'goły', 'skończony' w 吃光 chīguāng 'jeść' + 'skończony' = 'zjeść do końca', 尽 jìn 'wyczerpać' w 用尽 yòngjìn 'użyć' + 'wyczerpać' = 'zużyć'.

Künstler (2000:197) zwraca uwagę na to, że postpozycyjne określenia rezultatywne i kierunkowe nie tworzą wraz z czasownikiem struktur nierozdzielnych. Oznacza to, że między poszczególnymi komponentami czasowników komplementywnych może pojawić się inny element. Zajdler (2005:73) podaje przykład syntagmy kierunkowej 跑出来 păochūlái 'wybiec w kierunku osoby mówiącej’, w której złożone dopełnienie kierunkowe, czyli postwerb kierunkowy, rozbity jest przez postwerbalną grupę nominalną 屋子 $w \bar{u} z i$ 'pokój', jak w 小猫跑出屋子来了 xiăo māo păochū wūzi lái le 'mały kot wybiegł z pokoju w kierunku osoby mówiącej'.

Według Hu (1995:214-215) w niektórych przypadkach między człony konstrukcji komplementywnej można wstawić partykułę potencjalną 得 de lub 不 $b u$, tworząc ich formy potencjalne. Tak np. z czasownika rezultatywnego 认清 rènqīng 'znać' + 'jasny' = 'rozpoznawać' tworzy się jego formy potencjalne 认得清 rèndeqīng 'być $\mathrm{w}$ stanie rozpoznać' oraz 认不清 rènbuqīng 'nie być w stanie rozpoznać'. Konstrukcje zawierające partykułę potencjalną 得 de lub 不 $b u$ zwane są syntagmami bądź czasownikami potencjalnymi. Zajdler $(2005: 61,81)$ zaznacza, że w przypadku niektórych syntagm z dopełnieniem komplementywnym nie jest możliwe utworzenie ich form potencjalnych. Takimi są np. 病死 bìngš̌ 'być chorym' + 'umierać = 'umrzeć w rezultacie choroby', 走累 zǒulèi 'iść' + 'zmęczony' = 'być zmęczonym w rezultacie chodzenia'. Zajdler mówi również o takich syntagmach, które z pozoru wydają się być formami potencjalnymi, utworzonymi od syntagm czasownikowo-dopełnieniowych. W ich Jednak przypadku nie istnieje żadna forma wyjściowa, od której byłyby utworzone. Do takich częściowo zgramatykalizowanych i zleksykalizowanych syntagm zalicza np. 买得起 măideq ǐ 'móc pozwolić sobie na zakup' oraz 买不起 măibuq̌ 'nie móc pozwolić sobie na zakup'.

\section{STRUKTURY SPIĘTRZONE}

Według Hu (1995:215) wewnętrzna struktura wyrazów semantemowych złożonych $\mathrm{z}$ więcej niż dwu sylab może być kombinacją różnych relacji składniowych, zachodzących między poszczególnymi morfemami danego wyrazu, przy czym jedna ze struktur zawsze jest strukturą nadrzędną. Hu 
wymienia np. struktury spiętrzone będące połączeniem nadrzędnej struktury determinacyjnej $\mathrm{z}$ koordynacją lub predykacją. Wyraz 试验田 shìyàntián 'teren badawczy' (dosł. pole, na którym się eksperymentuje) zbudowany jest z dwu głównych członów: 试验 shìyàn 'eksperymentować' i 田 tián 'pole'. Relacja składniowa zachodząca między tymi członami to determinacja. Człon pierwszy zbudowany jest na zasadzie koordynacji z morfemów 试 shì 'testować' i 验 yàn 'sprawdzać'. Innym przykładem jest wyraz 人造丝 rénzàosī 'sztuczny jedwab' (dosł. jedwab wytwarzany przez człowieka), w którym główny podział przypada między człony 人造 rénzào 'sztuczny' i 丝 $s \bar{l}$ 'jedwab' połączone ze sobą relacją determinacji. Pierwszy człon to wyraz o strukturze podmiotowo-orzeczeniowej, w której semantem 人 rén 'człowiek' pełni funkcję podmiotu, a semantem 造 zào 'tworzyć' funkcję orzeczenia. Innym rodzajem spiętrzenia, które wymienia Künstler (2000:233), jest połączenie nadrzędnej struktury determinacyjnej z rekcją, jak w wyrazie 挖泥船 wāníchuán 'pogłębiarka' (dosł. statek kopiący błoto), gdzie rekcja 挖泥 wāní 'kopać błoto' określa 船 chuán 'statek'.

Künstler (2000:233) zauważa, że pośród struktur spiętrzonych zdecydowanie przeważają spiętrzone determinacje. Do takich należą np. 温度表 wēndùbiăo 'termometr' (dosł. wskaźnik stopni ciepła) oraz 热水瓶 rèshuĭping 'termos' (dosł. butelka na gorącą wodę). Struktura determinacyjna 温度 wēndù 'temperatura' składająca się z semantemów 温 wēn 'ciepło' i 度 dù 'stopień' jako całość jest określeniem semantemu 表 biăo ‘wskaźnik'. W kolejnym przykładzie semantem 瓶 ping 'butelka' określany jest przez determinację 热水 rèshul̆ 'gorąca woda', w której semantem 热 rè 'gorący' jest określeniem semantemu 水 shǔ̃ 'woda'.

\section{FORMACJE SYNTETYCZNE}

Poza wyrazami monomorfemicznymi, reduplikacjami, formacjami afiksalnymi i formacjami semantemowymi o wewnętrznej strukturze składniowej w języku chińskim występuje dość duża grupa wyrazów, których struktury są niejako syntezą różnych typów wcześniej opisanych struktur.

Jednym ze sposobów tworzenia wyrazów jest, według Zhu (1998:34-35), przyłączenie afiksu do wyrazu o wewnętrznej strukturze składniowej. Do wyrazu semantemowego 瓜子 guāž̌ 'pestka dyni', zbudowanego determinacyjnie z semantemów 瓜 guā 'dynia' i 子 $z \check{l}$ 'pestka', dołączony został sufiks rzeczownikowy 儿 -er, tworząc wyraz 瓜子儿 guāzǐr 'pestka dyni'. 
W tym przypadku przyłączenie sufiksu 儿 -er nie zmieniło znaczenia nowo powstałego wyrazu. Do wyrazu semantemowego o wewnętrznej strukturze składniowej można również przyłączyć prefiks. Künstler $(2000: 233)$ podaje przykład 反革命 făngéming 'antyrewolucyjny' (dosł. przeciw obaleniu mandatu), w którym 革命 géming 'rewolucja' (dosł. obalić mandat) to struktura rekcyjna, którą poprzedza quasi-prefiks 反 făn- o znaczeniu 'anty-', 'przeciw-'.

Do wyrazu o wewnętrznej strukturze składniowej można przyłączyć kilka sufiksów. Hu (1995:209) podaje wyraz 物理学家 wùlǔxuéjiā 'fizyk' (dosł. badacz nauki zajmującej się teorią materii), w którym do determinacji 物理 wùll̆ 'fizyka', składającego się z semantemów 物 wù 'rzecz', 'materia' i 理 $l \grave{l}$ 'teoria', dołączony został quasi-sufiks 学 -xué 'nauka', tworząc wyraz wùlǐ$x u e ́$ 'fizyka', do którego następnie został dołączony quasi-sufiks 家 -jiā 'badacz'.

Oprócz wyżej opisanych istnieją również takie wyrazy, które zbudowane są z wyrazu o wewnętrznej strukturze składniowej, do którego dołączony jest zarówno prefiks, jak i sufiks. Künstler wymienia np. 超现实主义 chāoxiànshizhǔyì 'surrealizm', w którym do rekcji 现实 xiànshí 'rzeczywistość' (dosł. pokazywać to, co realne) dołączony jest quasi-prefiks 超 chāo'ponad-', 'super-', 'ultra-', tworząc przymiotnik 超现实 chāoxiànshí 'surrealistyczny' (dosł. ponad rzeczywistością). Do całości dołączony jest jeszcze sufiks 主义 -zhŭyì '-izm' o pierwotnym znaczeniu 'doktryna', co daje dość skomplikowaną strukturę 超现实主义 chāoxiànshizhǔyì 'surrealizm' (dosł. doktryna mówiąca o tym, co jest ponad pokazywaniem tego, co realne).

Inny sposób tworzenia wyrazów to - jak podaje Zhu (1998:34-35) - przyłączenie sufiksu bądź sufiksów do reduplikacji. U Chao (1968:201) znajdujemy przykład 蝈蝈儿 guōguor 'amerykański konik polny', w którym do wyrazu o strukturze reduplikacji 蝈蝈 guōguo 'amerykański konik polny' dodany został sufiks rzeczownikowy 儿 -er.

Mniej liczne są połączenia reduplikacji z monosylabicznym semantemem lub polisylabicznym wyrazem semantemowym na zasadzie relacji składniowej. Hu (1995:200) wymienia np. 蜘蛛网 zhīzhūwăng 'sieć pajęcza', gdzie wyraz o strukturze reduplikacji typu ,shuangsheng” 蜘蛛 zhīzhu 'pająk' połączony jest determinacyjnie z semantemem 网 wăng 'sieć'. Innym wyrazem tego typu jest 玫瑰红 méiguihóng 'czerwony jak róża', w którym reduplikacja typu „dieyun” 玫瑰 méigui 'róża' jest określeniem semantemu 红 hóng 'czerwony'. Chao (1968:202) podaje przykład 洋娃娃 yángwáwa 'lalka' (dosł. dziecko zza oceanu), w którym główny podział wyrazu przy- 
pada na semantem 洋 yáng 'ocean' połączony determinacyjnie z wyrazem o strukturze reduplikacji 娃娃 wáwa 'dziecko'.

Wyraz polisylabiczny monomorfemiczny może łączyć się z semantemem bądź wyrazem semantemowym na zasadzie relacji składniowych. Do bardzo nielicznych wyrazów tego typu należą te wymienione przez Hu (1995:200). Rzeczownik 奥林匹克村 àolínpìkècūn 'wioska olimpijska' składa się z polisylabicznego wyrazu monomorfemicznego 奥林匹克 àolínpikè 'olimpiada' i semantemu 村 cūn 'wioska', które łączy relacja determinacji. Kolejnym przykładem jest rzeczownik 巧克力饼干 qiăokèlib̌̌nggān 'ciastko czekoladowe', w którym wyraz monomorfemiczny polisylabiczny 巧克力 qiăokèlì 'czekolada' jest określeniem wyrazu 饼干 bǐnggān 'ciastko', zbudowanego koordynacyjnie z semantemów 饼 bǐng 'okrągłe płaskie ciasto’ oraz 干 gān 'tarcza'.

\section{BIBLIOGRAFIA}

O P R A C O W A N I A

Chao, Yuan Ren. A Grammar of Spoken Chinese. 趙元任《中国话的文法》. Berkeley: University of California Press, 1968.

Chen, Guanglei. Hanyu cifa lun. Xuelin chubanshe. Shanghai. 陈光否《汉语词法论》. Xuelin Chubanshe, 2001.

Hermanová-Novotná, Zdenka. Affix-Like Word-Formation Patterns in Modern Chinese. Prague: Oriental Institute in Academia, 1969.

Hu, Yushu (red.), Xiandai hanyu. Gaodeng xuexiao wenke jiaocai. 胡裕树 主编《现代汉 语 高等学校文科教材》. Szanghaj: Jiaoyu Chubanshe.

Kratochvíl, Paul. The Chinese Language Today. Features of an Emerging Standard, London: Hutchinson University Library, 1968.

KÜNSTLER, MieczySŁaW J. Języki chińskie. Warszawa: Wydawnictwo Akademickie Dialog, 2000.

Li, Charles N.; Thompson, SAndra A., Mandarin Chinese. A Functional Reference Grammar. Berkeley and Los Angeles: University of California Press, 1981.

Packard, Jerome L. The Morphology of Chinese. A Linguistic and Cognitive Approach. 《汉语形态学: 语言认知研究法》. Beijing: Foreign Language Teaching and Research Press. Cambridge University Press, 2000.

TABAKOwSKA, ElżBIETA (red.). Kognitywne podstawy języka i językoznawstwa. Kraków: Universitas 2001.

ZAJDLER, EWA. Gramatyka współczesnego języka chińskiego. Składnia i semantyka. Warszawa: Wydawnictwo Akademickie Dialog, 2005.

Zhang, Bin. Xiandai hanyu yufa fenxi. Huadong shifan daxue chubanshe. Shanghai. 张斌 《现代汉语语法分析》. Szanghaj: Huadong Shifan Daxue Chubanshe, 2000.

ZHu, DeXI. Yufa jiangyi. Shangwu Yinshuguan. Beijing. 朱德熙《语法讲义》. Beijing: Shangwu Yinshuguan, 1998.

Zhu, YaJun; Tian, Yu. Xiandai hanyu cizhui de xingzhi jiqi fenlei yanjiu. 朱亚军, 田宇 《现代汉语词缀的性质及其分类研究》. „Xueshu jiaoliu”, 2000, 2:134-137. 


\section{S ŁOWNIKI I ENCYKLOPEDIE}

Golą, Zbigniew; Heinz, Adam; Polański, KaZimierz. Slownik terminologii językoznawczej. Państwowe Wydawnictwo Naukowe. Warszawa: Państwowe Wydawnictwo Naukowe, 1970.

PolAŃSKI, KAZIMIERZ (red.). Encyklopedia językoznawstwa ogólnego [EJO]. Wrocław: Ossolineum 2003.

Xiandai hanyu cidian 《现代汉语词典》[Słownik współczesnego języka chińskiego]. Beijing: Shangwu Yinshuguan, 2001.

\section{STRUKTURY WEWNĄTRZWYRAZOWE WSPÓŁCZESNEGO OGÓLNONARODOWEGO JĘZYKA CHIŃSKIEGO}

\section{Streszczenie}

Tematem niniejszego artykułu jest opis struktur wewnątrzwyrazowych we współczesnym ogólnonarodowym języku chińskim. W pięciu częściach omawia się kolejno: wyrazy monomorfemiczne, reduplikacje, formacje afiksalne, formacje semantemowe o wewnętrznej strukturze składniowej oraz formacje syntetyczne. Słownictwo poddane analizie to wyrazy polisylabiczne, również te o statusie wyrazów złożonych.

Wyrazy monomorfemiczne polisylabiczne wraz z krótkim odniesieniem do wyrazów monomorfemicznych monosylabiczych przedstawione są w części pierwszej artykułu. Część druga opisuje budowę wyrazów o strukturze reduplikacji z uwzględnieniem ich szczególnego typu - reduplikacji złamanych. W części trzeciej zaprezentowane są formacje afiksalne, obejmujące zarówno wyrazy zawierające afiksy właściwe, jak i quasi-afiksy. Wyrazy semantemowe o strukturze podmiotowo-orzeczeniowej, koordynacyjnej, determinacyjnej, rekcyjnej i komplementywnej, a także wyrazy wielosemantemowe zawierające spiętrzone struktury składniowe omówione są w części czwartej. Rozmaite typy formacji syntetycznych, to jest wyrazów powstałych na skutek połączenia różnych typów struktur wewnątrzwyrazowych, przedstawione są w części piątej.

Słowa kluczowe: współczesny ogólnonarodowy język chiński, struktury wewnątrzwyrazowe, wyrazy monomorfemiczne, reduplikacje, formacje afiksalne, formacje semantemowe o wewnętrznej strukturze składniowej, formacje syntetyczne, wyrazy polisylabiczne, afiksy właściwe, quasi-afiksy.

Key words: Modern Standard Chinese, inside word structures, monomorphemic words, reduplication, affix formations, semanteme formations with the internal syntactic structure, synthetic formations, polysyllabic words, appropriate affixes, quasi-affixes. 